\title{
Legal Protection for Human Trafficking Victim, Especially Women and Children in West Kalimantan
}

\author{
Yenny AS ${ }^{1}$, Nurfitriawati ${ }^{2}$, Klara Dawi ${ }^{3}$, Sri Ayu Septinawati ${ }^{4}$ \\ Faculty of Law Panca Bhakti University ${ }^{1}$ \\ venny.upb@gmail.com ${ }^{1}$
}

\author{
Keywords: \\ Legal Protection, Victim, \\ Trafficking, Women and \\ Children
}

\begin{abstract}
West Kalimantan Province, as one of provinces in Indonesia which has specific geographical condition is bordering with East Malaysia through official CrossBorder Post between Entikong and Tebedu, Badau and Lubuk Antu, Aruk and Biawak, and no less than fifty path ways (not official) can be passed to get in and get out to and from East Malaysia region. This geographical encouraged trafficking improvement to abroad with various modes. In fact, trafficking was affected by many factors, including stigma, poverty, lack of education, family resilience, and other factors, where women and children are the victim. The aim of this research to reveal how is the legal protection for the victim. Although there were many studies had been done about it, but the focus of this research is the obstacles face to give legal protection for the victims of trafficking in West Kalimantan border, where the top of the problem is victims role, sometimes they don't realize that they are the victims, so legal protection effort as stipulated in Trafficking Rules was not optimal. Through socio-legal research found an interesting thing, the lack of victim realized they were victims who have to get legal protection, so complicated a legal assistant for legal effort. Beside of that, trafficking as transnational crime and organized, it is complicated for legal enforcement, because of trafficking perpetrators are in the state border cross. The abstract contains: research objectives, implementation methods, analysis techniques and activity results. Typed with font Times New Roman letter 11, single space, and italicized.
\end{abstract}

\section{INTRODUCTION}

The rise of women and children trafficking today is a problem faced by Indonesia nation. Trafficking issue is a global phenomenon, and trafficking cases both between countries and within a country have been done by organized networks, even the reality shows that as the economy gets worse, more and more women and children are employed, trafficked and abused.

Human Trafficking, especially women and children from Indonesia to overseas has become rampant as widespread sending of women laborers abroad. Many cases of fraud committed by syndicates 
where to prospective migrant workers are promised jobs, but they are trafficked into forced prostitution, even illegal migrant workers expelled from Malaysia become targets of trafficking syndicates.

West Kalimantan Province has specific geographical condition which directly bordering on other country (East Malaysia) through Entikong and Tebedu and less than 60 (fifty) paths (unofficial) Cross Border Posts which can be traversed for entry and exit to and from the territory of East Malaysia. The geographical location of West Kalimantan Province, encourages the increasing trafficking practices abroad.

The involvement of an international criminal trafficking syndicate network through the Trans-national Cross Border can not be separated from the strategic position, where human traffic flow has no trouble getting out and entering. This makes trafficking easier. Various modus operandi that occurred among others recruitment and delivery of human (especially women and children), starting from the bottom level, that is by coming to areas of sending centers of migrant workers residing in the villages in the district. Starting from the way brokers seek directly to the villages, it often involves community leaders/village officials/local hamlets who act as intermediaries with the families of women and children. Then the calo persuades the parent or relative's family, and if difficult, the broker involves the intermediaries to convince them. The next step is that the woman and the child are handed over to another party to make the passport, and taken to the shelter and transferred to another party (agent/brokers), then the price transaction occurs, after which the broker offers the employer in need of labor and is employed at various places, such as households, restaurants, entertainment venues, karaoke and so on, with prices varying from $1,000-4,000 \mathrm{RM}$ or about 2.500 .000 IDR - up to $10,000,000$ IDR.

In addition to the modus operandi mentioned above, there are various other modus operandi, namely through marriage between woman (amoy) West Kalimantan with foreign man, such as Taiwan, Hongkong, Singapore, through mail order bride service, where foreign man or through the candidate is coming to Indonesia to seek and choose the bride (generally a woman of ethnic Chinese, because in the culture and tradition of marriage of Chinese society, a legal marriage is marked with a photo together with the bride and groom, so it does not have to fulfill the administrative requirements of the correspondence past and other parties). Victims of mail order bride services are mostly people from the bottom layer (poor). For one bride, the brokers will earn around 7-10 million IDR, from the cost of the marriage package issued by 60-70 million IDR,

There are many other forms of trafficking in women and children that are prevalent in people's lives, including where women and children are employed as domestic workers outside their consent and wishes, as well as women and children employed in entertainment or other places of employment, employed as sex workers, beggars and so forth. In general, the root causes of trafficking are the factors of consumerism, economic/poverty, the narrowness of employment, the low level of education and the lack of assertiveness of the legal apparatus in taking action against traffickers. The crime of trafficking is commonly associated with transnational crime. These groups of criminals choose to trade human beings (women and children) because the benefits are large and until now the risks are still relatively small, because unlike other commodities, human beings can be traded repeatedly and do not require large capital.

Given this trafficking is organized crime that is done neatly and clandestinely, so the fact that the actual number of victims is difficult to know/tracked. Quantitatively the actual facts can be much greater than the data or reports revealed. Given that crimes of trafficking are organized crime, it becomes increasingly difficult to prevent and mitigate them without intensive and coherent coordination among the relevant Government and agencies, as well as the community. 


\section{METHOD}

This legal research used socio-legal reseach with a qualitative approach, its bases study on the behavioral aspects of the law, by examining empirical realities conducted within the microanalysis level.

\section{DISCUSSION AND ANALYSIS}

\section{A. Trafficking Empirical Fact in West Kalimantan}

Human trafficking issue, especially women and children trafficking, is a global phenomenon occurred almost all over the world, between countries and within a state carried out by organized networks. Human trafficking, especially women and children from Indonesia to other country has become rampant along with the widespread sending of Indonesian Migrant Workers (migrant workers) abroad. There are many cases of fraud committed by syndicates where prospective labor migrants are promised will get a good job, but at last they are trafficked into forced prostitution, and even illegal migrant workers expelled from Malaysia are subjected to trafficking syndicates.

West Kalimantan Province, which has a specific geographical condition which directly borders abroad (East Malaysia) through the Entikong and Tebedu Official Entrance. Even, no less than 55 (fifty five) paths (unofficial) that can be traversed for entry and exit to and from the territory of East Malaysia. The geographical location of West Kalimantan Province, encourages the increasing of trafficking practices to abroad. Generally, human trafficking cases that occurred in West Kalimantan in the forms of: labor exploitation, sex exploitation and children exploitation, slavery and male order bride.

Empirical facts show the following common modus operandi are:

\section{Exploitation of Migrant Workers (Slavery)}

Indonesian Workers / Women Laborers who are promised will get an informal job such as Housemaid, Shop Waiter, Factory Worker or Restaurant Waiter. Then sent and received by the agent in the destination country. In the country they are employed as slaves, they were not getting their rights as workers such as salary and rest periods and should not leave the workplace in addition to physical, psychological or sexual abuse.

\section{Prostitution Exploitation}

Prospective workers are promised to work as informal workers such as domestic servants, restaurant waiters, nannies and so on, are prostituted both inside and outside the country. Traffickers, not only prostitutes victims in the localization of ordinary prostitution but also organize this crime by bringing casualties to hotels and doing transactions there. Victims are usually confined in an apartment room then taken out to serve customers in hotels where the offender meets with customers and customers are free to choose victims. The perpetrator is transacting with the customer while the victim has no power to resist especially with the strict guarding of the bodyguards being forced to serve the customer. The victim is forced to serve a number of men in one day and is forbidden to leave the localization before paying some money that is considered debt to pimps then the victim can not do anything. Prostitution exploitation can also occur at the plantation site, where the perpetrator organizes this activity at a remote plantation site targeting the customers of the plantation workers.

\section{Forced Labor}

Mature boys and children are offered jobs in plantations, timber mills or construction workers abroad and are promised a high salary and house facility prepared by the Company. Arriving at the work site, the victim is forced to work without salary and un adequate rest, are prohibited leaving from workplace and do not get a decent residence or those exploited in the plantation area usually stay in 
permanent hobbies and prohibited from leaving the workplace before they finish contracts (usually 2 years). More pathetic, sometimes when the job is almost complete the perpetrator reports to the local Police about their normally undocumented whereas they were arrested by the Police and deemed to be breaking the rules to Immigration and of course the perpetrators do not have to pay their salaries.

\section{Kidnapping}

The teenage daughters were abducted while returning from school and then sedated and moved for prostitution. Frequent anesthesia against adult victims is usually in the public transport, for example inter-city buses.

\section{Male Order Bride}

The victim is promised to be married to a foreign citizen but later by her husband in making the housekeeper or even prostituted. The common trafficking facts in West Kalimantan in the form of labor exploitation which the tendency of many Indonesian migrant workers come from outside West Kalimantan, are generally imported from various regions in Java or East Nusa Tenggara whether imported or unofficial Indonesian Manpower Service Submitter, or groups of syndicates, before they are put into Sarawak, the migrant workers are accommodated in several shelters located in Pontianak and Sanggau, for the handling of passports or ID cards performed both in Entikong (Sanggau District), Pontianak City, Singkawang City and Sambas District. Usually For the maintenance of ID cards in Entikong Village will be charged by 200.000 IDR per person, while for the passport fee issued by 700.000 IDR until 900.000 per person.

After the process of Identity Card obtaining and Passport is complete, then the next Candidate Indonesian Workers is taken to Entikong by agent or syndicate, to then submitted to agent or syndicate Entikong-Sarawak, who had waited before, then by the agent or syndicate, the TKI is submitted to agent or syndicate that waits on the Border in Sarawak, then after they are handed over to agent or syndicate on the Sarawak-Entikong border. Furthermore, when prospective migrant workers have arrived in the hands of agent or syndicate in the Border of Sarawak-Entikong, then they are taken again to agent or syndicate located in Sarawak or Kuching to be submitted to agent shelter in Sarawak. After they are in the shelter, then, agent allocate prospective migrant workers to various employers who require such good labor as domestic workers, prostitutes, waiters, etc. This is where the goal of trafficking takes place, where prospective migrant workers are discharged not in accordance with what is promised/recalled when they are recruited and dispatched, but instead become slaves, abused, sex workers and prostituted, so that victims can't escape from the current situation ditrafik, because the passport is detained by the employer. While recruited and well organized brokers/agents have benefited from it.

Besides, there is also the fact of the trafficking mode in the form of male order bride, which commonly happened in Singkawang City, where generally the victim are females (amoy) from Chinese ethnic in Singkawang who has the legal culture of marriage according to Chinese custom is bride photo only. Utilizing the poverty vulnerability of Chinese residents on the outskirts of Singkawang City brokers who acted as matchmakers introduced men from Taiwan to marry the amoy, who later received the consent of the victim's parents, amoy (the victim) was then taken and dispatched to Singkawang for married by way of taking pictures, then taken to Taiwan without the procedure of marriage execution that was registered especially the marriage registration with foreigners. Once in Taiwan, there are victims who then dtraffic become prostitutes or forced laborers, and have no empowerment to return to his family.

Trafficking facts in West Kalimantan have not been recorded accurately, although trafficking has been conducted since 2007 after the issuance of Eradication of Crime of Human Trafficking Law 21 of 2007, considering the mode that occurs in various forms and indicated that many victims are not report to law enforcement officers and do not feel as human trafficking victim, so there is no accurate data about the act of handling trafficking cases handled legally. Below is the human trafficking cases 
handled by the Local Police of Women and Children Protection Unit in West Kalimantan and Integrated Service Center for Women and Children Protection in West Kalimantan Province

Table 1

Data of Trafficking Cases Handled by Authorized Apparatus

\begin{tabular}{cccc}
\hline No & Year & $\begin{array}{c}\text { Cases are Handled by } \\
\text { West Kalimantan } \\
\text { Local Police Women } \\
\text { and Children } \\
\text { Protection }\end{array}$ & $\begin{array}{c}\text { Province Integrated } \\
\text { Service Center for the } \\
\text { Protection of Women and } \\
\text { Children }\end{array}$ \\
\hline 1 & 2012 & 21 & 17 \\
2 & 2013 & 12 & 11 \\
3 & 2014 & 16 & 8 \\
4 & 2015 & 11 & 11 \\
5 & 2016 & 15 & 9 \\
6 & 2017 & 13 & 5 \\
\hline & & & Source: Processed Field Research
\end{tabular}

Human trafficking cases reality in West Kalimantan, although some cases have been handled legally and today the perpetrators can be charged with legal provisions as regulated in Eradication of Crime of Human Trafficking Law 21 of 2007. But the most important and crucial is the importance of mechanisms and cooperation in handling it, especially the effort to provide legal protection against trafficking victim, especially women and children.

\section{B. Legal Protection Constraints Against Human Trafficking Victims}

Human Trafficking victim as defined in Article 1 Sub-Article 3 of Eradication of Crime of Human Trafficking Law 21 of 2007 is a person suffering from psychological, mental, physical, sexual, economic, and/or social suffering resulting from the crime of human trafficking. Human Trafficking Crime as defined in Article 1 Sub-Article 2 of Eradication of Crime of Human Trafficking Law 21 Year 2007 is any action or set of actions that fulfills the elements of the offenses set out in this Law.

The elements of an act as Human Trafficking are the act of recruiting, transporting, sheltering, shipping, transferring or persons receiving with violence threats, the use of force, abduction, capture, falsification, fraud, abuse of power or vulnerable positions, debt bondage or pay or benefits , obtaining the consent of the person in control of that other person, whether committed within the state or between countries, for the purpose of exploitation or made an exploitation of person.

Essentially, crime victims are the most suffering parties in a crime, including human trafficking criminal act, and the victim is also often in a vulnerable position, thus being powerless to act to defend himself from the protection of the law. Victims in the view of Arief Gosita (Widiartana, 2014) are those who suffer bodily and spiritually as a result of the actions of others who seek the fulfillment of self-interest or others who are in conflict with the interests and suffering human rights.

According to Teguh Prasetyo, taking Stanciu's opinion, the meaning of the victim (in the broad sense) is the person suffering from injustice. Thus, according to Stanciu, there are two basic attributes of the victim, both suffering and injustice (Siswanto Sunarso, 2012) Furthermore, Daniel Glaser (Widiartana, 2014) said "Victimis the person or organisation injured by a crime" The low position of victims in the handling of criminal cases is presented by Prassell (Lagalung, Pidana, Hukum, \& Hasanuddin, 2013) who pointed out "Victim was a forgotten figure in study of crime. Victm of assault, robbery, theft and other offences were ignored while police, courts, and academicians concentrated on known violator" 
Victims within the scope of ideology have a broad meaning because they are not only limited to individuals who actually suffer losses, but also groups, corporations, private and government (Siswanto Sunarso, 2012). Legal protection of victims of crime as part of the protection of the people can be manifested in various forms, such as through the provision of restitution and compensation, medical services and legal assistance (Rena Yulia, 2010).

Restitution is more directed at the responsibility of the perpetrator to the consequences caused by the crime so that the main target is to overcome all the losses suffered by the victim. Rejects used in determining the amount of restitution that is given is not easy in formulating it. It depends on the social status of the perpetrator and the victim. In the case of a victim with a lower social status than the perpetrator, he will give priority to compensation in the form of material, and vice versa if the victim's status is higher than the perpetrator, the restoration of the dignity and the good name will be preferred (Rena Yulia, 2010). In the Witness and Victim Protection Law formulates Restitution is a compensation provided to the victim or his family by the perpetrator or a third party

Compensation is a form of assistance that can be seen from humanitarian and human rights aspects. The idea of realizing the social welfare of the community based on commitment to social contract and social solidarity makes the society and state responsible and morally obliged to protect its citizens, especially those who experience disaster as a crime victim. Compensation as a form of compensation that is totally independent of how the judicial process and the judgments are passed, even the source of funds for that obtained from the government or general funds (Rena Yulia, 2010). More firmly in the Law on Protection of Witness and Victim Number 13 of 2006 as amended by Law Number 31 Year 2014, formulating Compensation is a compensation provided by the state because the perpetrator is unable to provide full compensation for his responsibility to the victim or his family.

While Amendment of Protection of Witnesses and Victims Law 13 of 2006 become Law 31 of 2014 formulated that protection is entirely in the effort to fulfill the right and provide assistance to provide a sense of security to witnesses and / or victims that must be carried out by the Institute Protection of Witnesses and Victims or other institutions in accordance with the provisions. This protection is provided in all stages of the criminal justice process within the jurisdiction.

In addition to Eradication of Human Trafficking Law 31 of 2014 on Amendment to Law 13 of 2006, Law 21 of 2007, also regulates the protection of witnesses and victims through Articles 43 to Article 55. Furthermore, through Article 60 to Article 63 also accommodated the participation of the community to assist the prevention and handling of human trafficking victims. Even the protection of victims of trafficking is not just a provision of restitution and compensation, but also includes some activities, including shelter in a safe place, repatriation (to their home or country), including legal aid and assistance, rehabilitation (health restoration, physical and psychological), reintegration (reintegration to their families or communities) and empowerment efforts (economic and educational) so that victims are not trapped back into trafficking. The protection effort of the victims is carried out by the Government of RI together with its partners: NGOs, local, national and international, community organizations, Institute of Community Service of Higher Education, and individuals concerned with this.

In addition, services to human trafficking victims are also provided by the Integrated Services Center of Women and Children, Women's Crisis Center at Regional Hospital and Bhayangkara Hospital, Trauma Center (shelter) in West Kalimantan Province. In providing legal protection against human trafficking victims, it is also encouraged to provide legal assistance through legal aid agencies, especially legal aid agencies providing free legal assistance services facilitated by the state through the Ministry of Justice and Human Rights, such as the Elipeka Legal Aid Institute. The institution provides legal assistance to the victim in order for trafficking victims to obtain their legal rights, either during investigation, prosecution, until court proceedings so that legal rights as a party to be protected are not violated and the victims are treated properly.

In reality, despite so many policies measures are taken in order to provide legal protection against 
human trafficking victims, especially women and children, there are still obstacles in the operationalization of their implementation. The constraints faced in the operationalization of its implementation are:

\section{The Lack of Victim Role}

Expressing the occurrence of human trafficking cases, the victim as a witness is expected to play a role in providing information during the incident, so that the elements proof of human trafficking crime can be revealed as legal facts, where the perpetrators can be charged with legal threat. However, in reality, trafficking victims, especially women and children, do not feel that they are human trafficking victims, as the fact that the victims are in vulnerable positions are recruited by trickery and debt bondage, then trafficked for labor exploitation and then tortured both physically and psychic, the victim just feels that he is in a disadvantaged state, then tries to run away from his employer and instead returns to contact the candidate (the perpetrator) to be accommodated and found another job, and while in the situation the victim is trying to hide from the apparatus law enforcement who will act to provide legal protection. This condition occurs because it is influenced by very low victim education and poverty vulnerability.

\section{Policies that Emphasize Rehabilitation and Reintegration of Victims}

Providing protection for human trafficking victims, government officials put more emphasis on the policy in rehabilitation efforts victims handling who prioritized victims rehabilitation, trauma and post rehabilitation immediately reintegration (the return of victims to their home areas), so that legal counseling process becomes did not last until it was completed, because the victim had been sent back to his home region. This reality is influenced by the psychological condition of the victim that can not last long in the integrated service center accommodated by the Government, because the traumatic feeling of exploitation must be reintegrated immediately to return to his family.

This rehabilitation policy is based on the provisions of Eradication of Crime of Human Trafficking Law 21 of 2007, rehabilitation is the recovery of disturbances to the physical, psychological, and social conditions in order to carry out its roles properly in the family and society. The provisions on rehabilitation itself based on Article 51 and Article 52 of Law 21 of 2007 are as follows:

a. The victim is entitled to health rehabilitation, social rehabilitation, repatriation, and social reintegration from the government if the person is suffering physically or psychically as a result of a person's trafficking crime.

b. Rehabilitation is proposed by the victim or family, friend, police, volunteer companion, or social worker, after the victim has reported his or her case to the police.

c. Applications are submitted to government through ministers or agencies dealing with health and social issues in the region.

\section{The Weak of Criminal Justice System in Handling Trafficking as Transnational and Organized Crime}

Legal protection against human trafficking victims is often faced with the unfinished constraint of law enforcement process, because the traffickers are in trans-state borders. This is because trafficking occurs as a transnational crime syndicate and organized crime, where the perpetrators consist of syndicates ranging from brokers recruiting victims from rural pockets who take advantage of the poverty of the victim's family, and brokers bring and recruit victims to a network of syndicates cross country borders, then the syndicate takes the victim again to another syndicate network for the purpose of trafficking, whether the victim is trafficked for the purpose of sexual exploitation, migrant workers or other forms of trafficking, so that the perpetrators are already abroad, it is then revealed that it is difficult for the criminal justice system to process the law, so that victims do not get their rights legally to be protected. Based on these constraints, it can be seen that the legal protection effort for trafficking victims has not been running optimally either due to the factors of the victims, as well as the perspective factor of the Government as the role occupant in providing legal protection to the victims prioritizing social policies such as rehabilitation and social reintegation, who have not been able to 
access transnational crime.

\section{CONCLUSION AND SUGGESTION}

Through the various obstacles descripe above, providing legal protection framework against victims of trafficking, when examined in a victimology perspective, especially in the framework of creating policies in the framework of reducing the suffering of the people, especially trafficking victims, an integral effort is needed in the handling of human trafficking cases in West Kalimantan. The integral

effort is a legal protection against trafficking victims by all parties in West Kalimantan.

\section{REFERENCES}

Lagalung, M., Pidana, B. H., Hukum, F., \& Hasanuddin, U. (2013). Legal Protection of Women and Children of Human Trafficking Victims.

Sunarso, S. (2012). Victimology in the Criminal Justice System. Jakarta: Sinar Grafika.

Widiartana. (2014). Victimology, Victim's Perspective in Crime Response. Yogyakarta: Cahaya Atma Pustaka.

Yulia, Rena. (2010). Victimology, Legal Protection Against Victims of Crime. Yogyakarta: Graha Ilmu. 